\title{
CHALlENGES IN IMPLEMENTATION OF AUTOMATED IDENTIFICATION TECHNOLOGY
}

\author{
STANKOVSKI, S. \& OSTOJIC, G
}

Abstract: Automated identification technology (AIT) relies on connection of a variety of identification devices in computer integrated system. These devices, such as bar codes, magnetic strips, smart cards, optical memory cards, RFID (Radio Frequency IDentification) tags, NFC (Near Field Communication) tags or/and biometrics (face, fingerprint, signature, voice, iris, retina, and DNA (Deoxyribonucleic Acid)) identification marks use for marking or tagging individual items, multi-packs, equipment, air pallets, or containers in applications such as tracking products and assets/supply chain, access control, health care systems, payments, etc. All devices are equipped with the hardware and software required to read the information on them, and integrate that information with other information in computer integrated system. Actually, AIT can be used in nearly every business in the world. This fact shows how many challenges and opportunities have in AIT. Depending on the application, the knowledge of AIT have to be combine with a specific knowledge of application domain, and knowledge of information technology. Because of that, typically implementation of AIT required multidisciplinary team. Also, AIT generates a lot of data which required significant memory capacity storage and advanced data mining techniques. In this chapter are presented several typical applications, primary based on RFID, including manufacturing production, access control, agricultural business, vending machines, payment, etc, and also challenges for the future implementation in industry and non industry.

Key words: Automated identification, RFID, NFC, applications, challenges
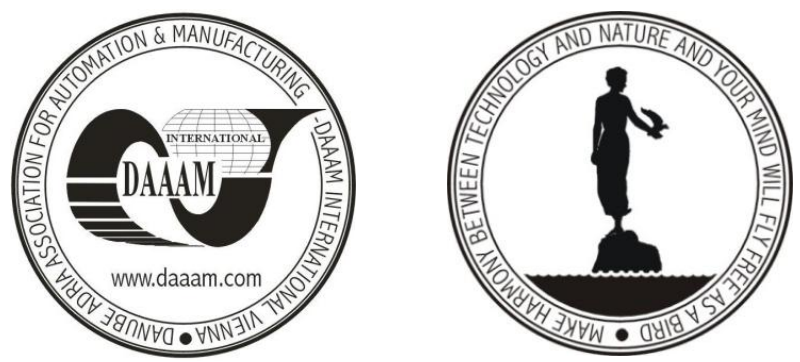

Authors' data: Univ.Prof. Dipl.-Ing. Stankovski, S[tevan]; Assistant Prof. Dr. Sc. Ostojic, G[ordana], University of Novi Sad, Faculty of Technical Sciences, Trg Dositeja Obradovića 6, 21000 Novi Sad, Serbia, stevan@uns.ac.rs, goca@uns.ac.rs.

This Publication has to be referred as: Stankovski, S[tevan] \& Ostojic, G[ordana] (2013) Challenges in Implementation of Automated Identification Technology, Chapter 02 in DAAAM International Scientific Book 2013, pp. 053-074, B. Katalinic \& Z. Tekic (Eds.), Published by DAAAM International, ISBN 978-3-901509-94-0, ISSN 1726-9687, Vienna, Austria

DOI: $10.2507 /$ daaam.scibook.2013.02 
Stankovski, S. \& Ostojic, G: Challenges in Implementation of Automated Identifica...

\section{Introduction}

Every company needs consistent data about their manufacturing/service operation, in order to wholly exploit production/service capacity. Automated identification technology (AIT) enables accurate data collection and it can be used in a wide range of applications. The applications vary from process automation (tracking products and assets/supply chain), health care systems, to access control (Turcua et al., 2013, Kärkkäinen et al., 2003, Karakostas, 2013). AIT relies on connection of a variety of identification devices in computer integrated system. These devices, such as bar codes, magnetic strips, smart cards, optical memory cards, RFID (Radio Frequency IDentification) tags (Lahiri, 2007), NFC (Near Field Communication) tags or/and biometrics (face, fingerprint, signature, voice, iris, retina, and DNA (Deoxyribonucleic Acid)) identification marks use for marking or tagging individual items, multi-packs, equipment, air pallets, containers, etc. All devices are equipped with the hardware and software required to read the information on them, and integrate that information with other information in computer integrated system. When AIT is properly implemented into a business, costs can be reduced and the business will become more competitive.

Nowadays, devices which are used in applications with AIT have enough power processor with unique number (called an IP (Internet Protocol) address) to be a part of network of computers. This capability is used to connect these devices in a network call Internet of Things (IoT) (Gubbi et al., 2013). IoT sometimes referred to as the Internet of Objects, will change a lot of things. The vision of IoT is to attach tiny devices to every single object to make it identifiable by its own unique IP address. These devices can then autonomously communicate with one another and any others processor in the network. It is out of question to ask how many challenges is open now. One of them is recently launched "Cloud of Things" initiative joins several ongoing projects at the Auto-ID Labs on MIT (Massachusetts Institute of Technology), to connect physical objects such as vehicles and buildings to the cloud. The "Cloud of Things" builds on the IoT, where information about objects is accessed via the Internet; and machine-to-machine (M2M) computing, where wireless communication protocols enable peer-to-peer exchange of data between electronic devices (http://web.mit.edu/newsoffice/2012/auto-id-cloud-of-things-bigdata.html). Similar projects based on AIT can be found at almost every university in the world.

Since 2005 year, Automated Identification Technology (AIT) is intensive researched at Department of Industrial Engineering and Management (DIEM), Faculty of Technical Sciences, University of Novi Sad. Main financial support is obtained through grants which are financed by the Ministry for Science and the Provincial Secretariat for Science and Technological Development. The grants: The implementation of RFID (Radio Frequency IDentification), RFID technology in the supply chain, Automated systems for identification and tracking of objects in industrial and non-industrial systems, are enabled research is several fields, like: manufacturing production, supply chain, access control, agricultural business, 
vending machines, payment, etc. The focus of this research is given to the use of RFID technology as the core technology for identification in most applications. Ones again, it is important to be noted that the successful implementation of the AIT depends on successfully connecting to the rest of an information system. In the text below will be will present the results achieved in the implementation of the AIT on the Department of Industrial Engineering. The first will be described in the general part about the RFID technology (Stankovski et al., 2009a, Stankovski et al., 2012). After this chapter, it will be present the results obtained in the fields of Product lifecycle management (Stankovski et al., 2010), and Agricultural business (Stankovski et al., 2012).

\section{RFID Technology}

RFID is a system for automated data acquisition which allows collection and wireless (radio wave) transfer of production- and business-related data. RFID technology is suitable for usage on plastic product/parts (Inkenzeller, 2003.). Since the moment, a product is manufactured, to the beginning of its exploitation or disassembly, RFID technology allows real-time identification, during delivery, storage, or any other process taking place within an enterprise. By means of radio waves, the data are acquisitioned and transferred in wireless mode between production and business processes in real time. This unique way of identification is adjusted in such a way that it allows the information on product to correspond to the information on the side of the company or the host system. Using RFID technology, it is possible to track products and equipment, with minimum human intervention. This can potentially cut back operating costs and increase real-time visibility during complete product life cycle.

RFID system consists of: a computer (or Programmable Logic Controller (PLC)), RFID reader, antenna (which can be integrated in a RFID reader) and transponder - tag (Fig. 1). The antenna is used to amplify the signal, which is emitted by the reader to the tag, as well as the signal, which is returned to the reader by the tag, which increases the tag-reading range. RFID reader can be a stationary or a portable device, which can activate and pick up the signals emitted by the tags. It consists of the power unit, antenna and a printed circuit board, and its primary role is to receive and send RF (Radio Frequency) signals to the tags by means of antenna. From a computer or a PLC, the reader receives instructions generated by the dedicated software. The control unit inside the reader executes the received instructions (Inkenzeller, 2003; Glover \& Bhatt, 2006).

The readers differ by the range and operating frequency. Similar to the tags, the readers can have small range (up to several centimetres), medium range (up to 1 meter), and long range (tens of meters, with an additional antenna). 


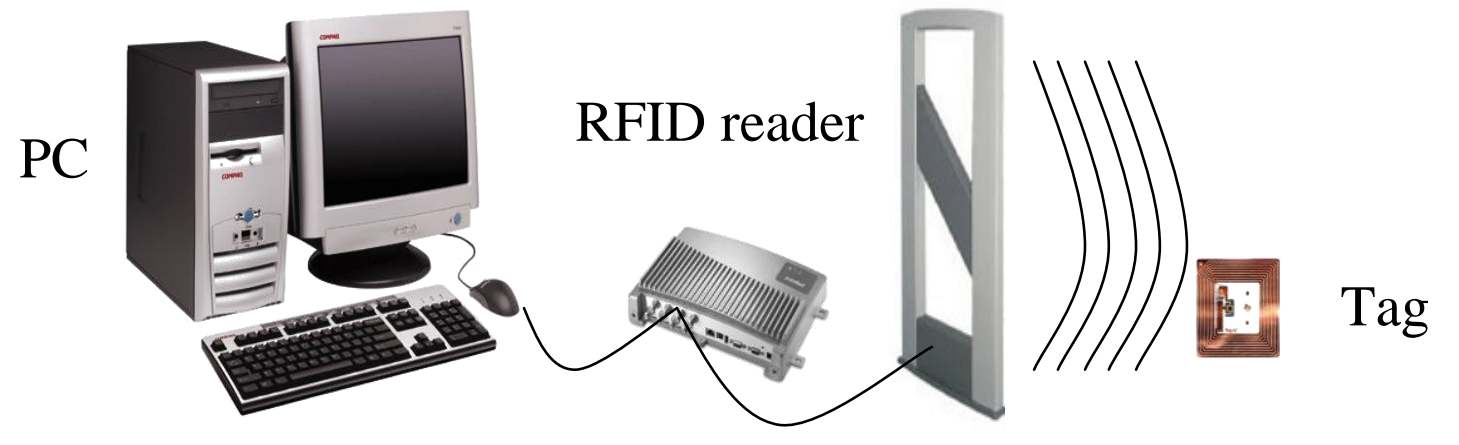

Antenna

Fig. 1. Basic components of RFID system (Stankovski et al., 2010)

The tags consist of a microchip (which stores alpha-numerical code for product labelling), an antenna (copper wire - coil) and an optional power source (e.g. battery). They exist in a variety of forms: various pendants, circular or square plates, magnetic cards, or some other form, depending on the area of application (Fig. 2). Smart labels are a special type of tags which can be placed on, or built into a palette or any sort of product.

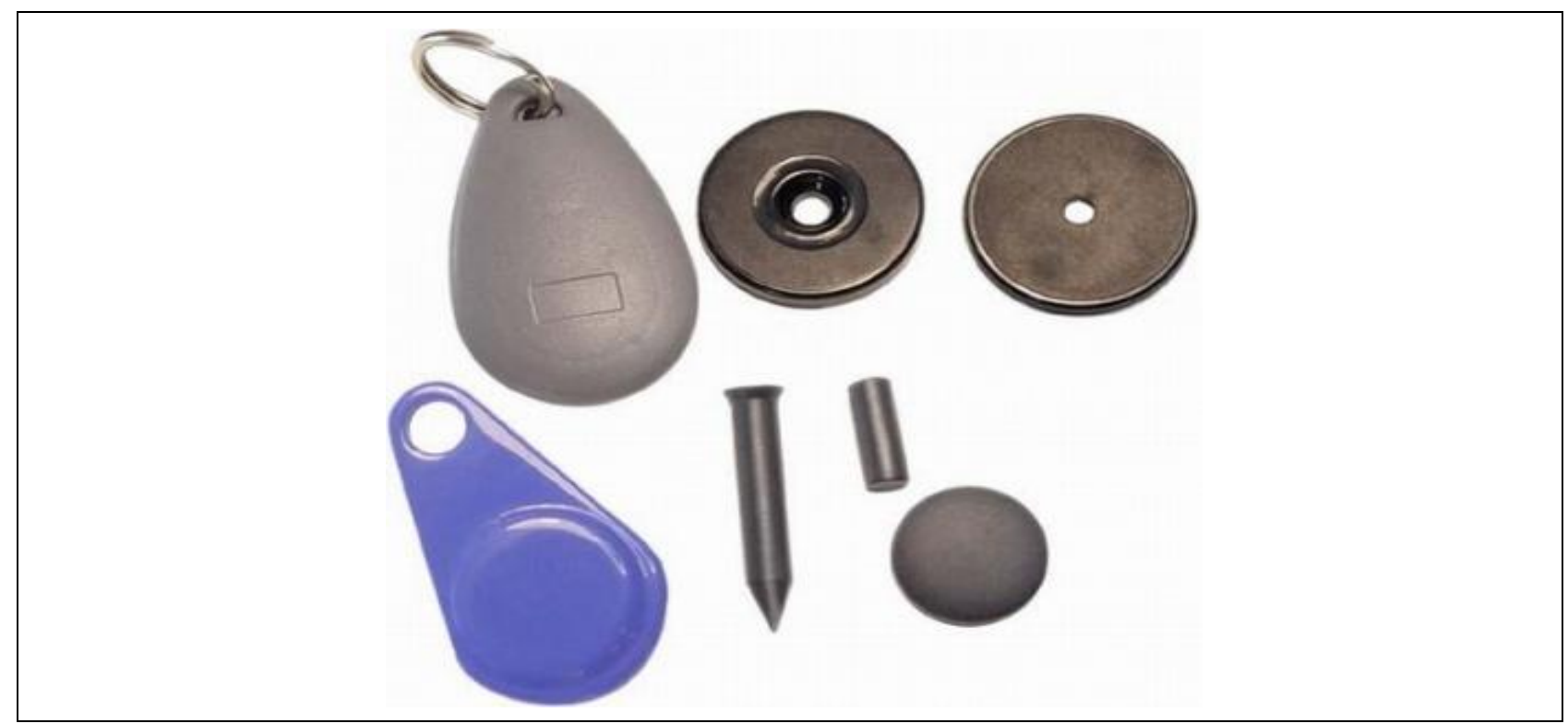

Fig. 2. Various forms of RFID tags (Stankovski et al., 2010)

The components of RFID systems are selected depending on the area of application. Of primary consequence is the operating frequency of the components (Fig. 3). In most of the countries, the operating frequencies for RFID systems are strictly defined.

Once RFID tag enters reader's operating range, the reader detects its activation signal. The reader then decodes the data coded in tag's integrated circuit and the data is transferred to the computer for processing. Significant advantage of RFID systems is that they do not require contact for proper functioning. Tags can be read in any industrial environment, which can involve snow, fog, ice, color stains, dirt and 
similar. RFID tags also read fast - in most cases the response is faster than 100 milliseconds. New generation of readers have ability to simultaneously read several tags. Thus whole storage area can be read at once instead of scanning each article individually (Shepard, 2005).

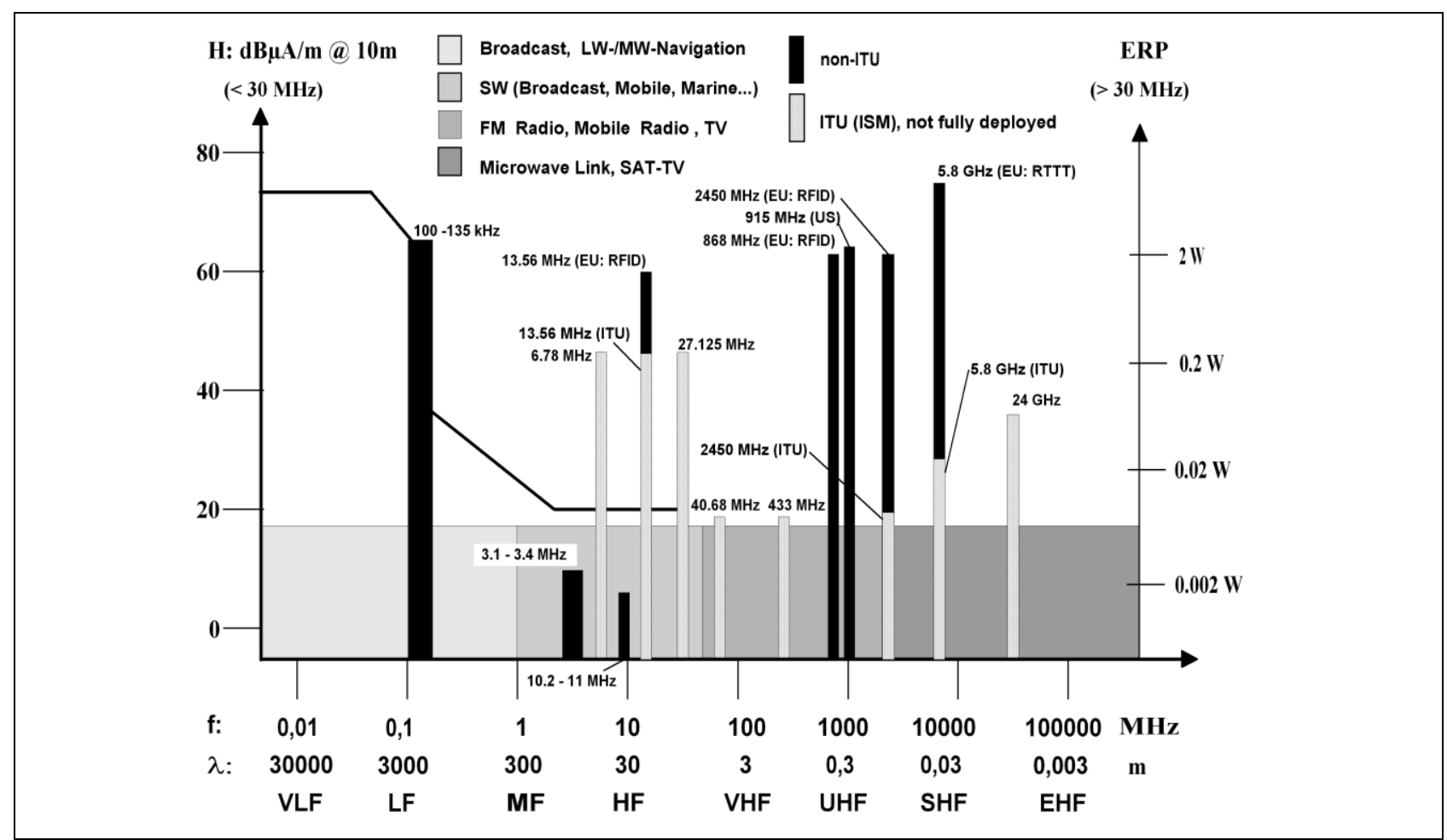

Fig. 3. Illustration showing the broad range of frequencies within the electromagnetic spectrum that RFID system can utilize (Stankovski et al., 2010)

\section{AIT in Product Lifecycle Management}

All phases of the product life cycle, starting from the first phase - production, following with distribution, sales, usage, service and maintenance to the phases coming at the end of the life cycle (disassembly, recycling, reassembly, incineration, waste disposal) is presented in Fig 4. It is important to emphasize that not every, but most of the products pass through the mentioned phases during their life cycle.

Disassembly is just one of the processes in the life cycle of a product and lately it has attracted a lot of attention, considering its key role in reassembling and recycling of products. This is due to ecological and economical reasons. The ecological side of the problem is seen in ending numerous products at waste dumps and in depletion of non-renewable natural riches. The economical side of the problem of disassembly is seen in the need for a design of the disassembly system in a way that the value of the disassembly process result is grater then the resources invested for its proper functioning (Lazarevic, 2009). When designing disassembly system the designer has to consider end of life strategies and strategies selection for product. 


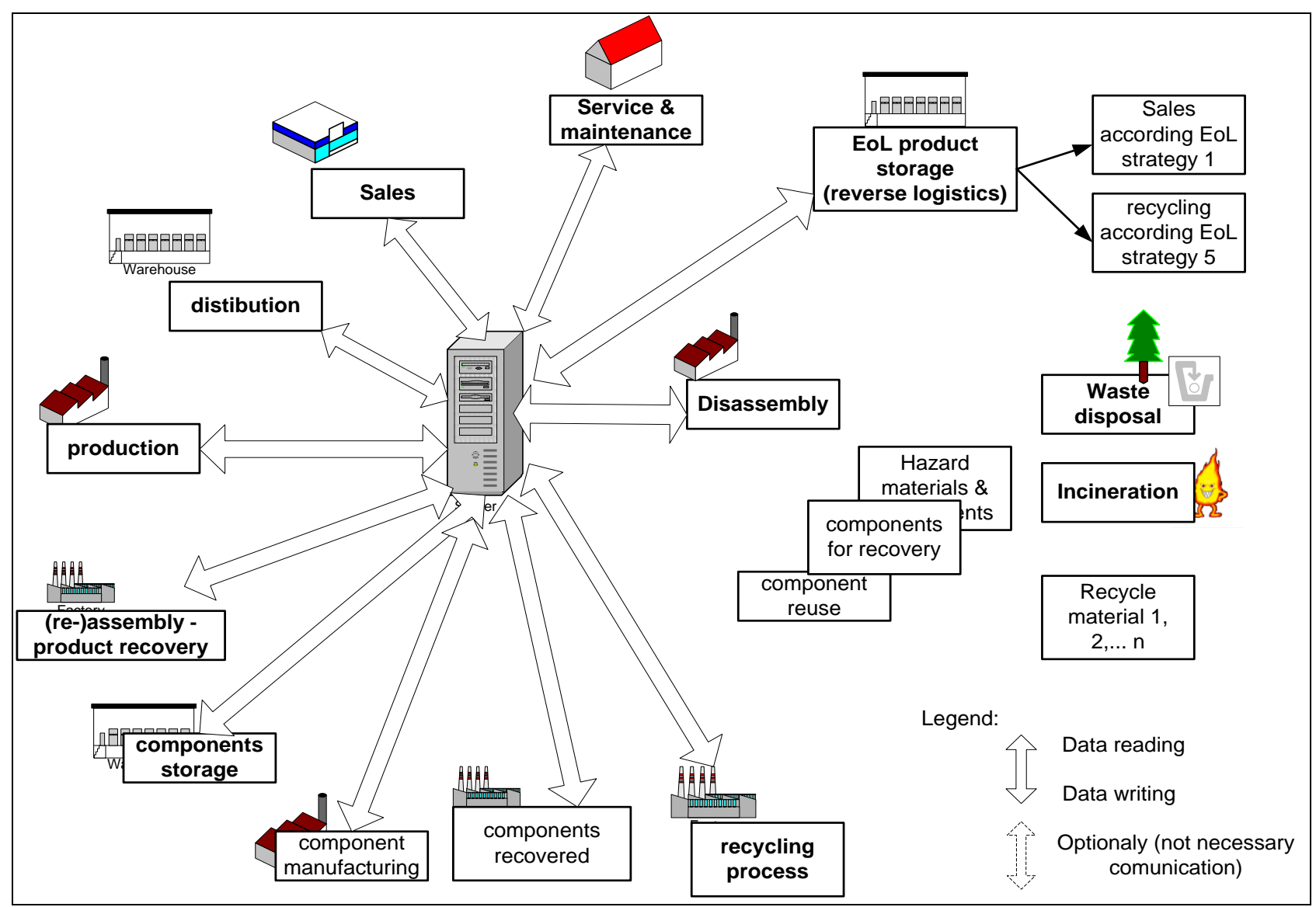

Fig. 4. Phases of product life (Stankovski et al., 2009a)

Users of products have two crucial difficult decisions to make: one is decision when to replace a product after its use and the other is what to do with the products when they decide to replace it. It is not unusual for some users to decide to sell the product and replace it while it is still in good condition. Therefore, the price of that kind of product is higher and the budget for buying a new, technologically advanced product is also higher. There are also some users which utilize their products until they became technologically outdated. After that, they leave them to the company responsible for end of life product processing. For many different reasons products arrive to the end of life product storage. Some of them may be discarded, but their vital elements can be in good condition, so they can be reused as spare parts in the maintenance process. All this leads to a conclusion that there is a need to determine strategies for the product at the end of life cycle.

Studies related with the strategies of the products end of a life cycle are numerous (Lazarevic, 2009; Mehl et al., 1994). The most accepted, and in its character, the most comprehensive classification of the products end of a life cycle is (Rose et al., 1999):

1) re-use of used products,

2) reconstruction of used products,

3) usage of already used products for spare parts,

4) recycling with disassembly,

5) recycling without disassembly,

6) dumping of the used products. 
Re-use of already used products is a strategy that organizes the return of discarded products which are still in function. If such an interest exists, already used products are sold in the market. Reconstruction of used products is applied due to modernize or to upgrade their performances. The purpose of this strategy is to attain a product, which is in quality less or very similar to the quality of the new products. The quality of the reconstructed products depends on the determined depth of disassembly. If a product is disassembled to the level of parts and a control and a replacement of all parts is conducted, the used products are brought to a high level of quality, required for the new products. Also, it is possible to conduct the modernization of products, by replacing certain modules with contemporary ones, after applying the disassembly. Appliance of already exploited products for spare parts is being frequently used. In certain companies, out of date products are being collected in an organized manner. The purpose of this strategy is to take a relatively small part of sub modules from a used product and use them for the above mentioned strategy, or for another purpose, and the rest will be used for material recycling. Recycling with disassembly is a strategy used for separating parts made of different material, before its conversion in the process of disassembly. The purpose of this strategy is to use the materials from the used products and parts, by separating them in the procedure of disassembly into the element parts and with appropriate selection, depending on the determined type of material. These materials can then be used in the production of original or some other products. Recycling without disassembly is a procedure, which is used to compact and compress the product and then crush it and sort it by type of material. Disposal is, from the ecological point of view, the most inconvenient strategy for disposing products on the waste dumps. Having the above mentioned strategies in mind, it is necessary to design an appropriate production system. The system for product processing at the end of life cycle has a quite complex structure, since there is a need for more then one technologically different subsystem like (Lazarevic, 2009):

1. disassembly,

2. reassembly,

3. recycling,

4. waste incineration,

5. hazardous waste storage,

6. waste storage.

The choice of strategies for reconstruction of used products (2), usage of already used products for spare parts (3) and recycling with disassembly (4) are made according with the both momentary product condition and suggestions taken from the database for particular product. A system for product processing, according with chosen strategies for product management at the end of the life cycle, is shown in the next figure (Lazarevic, 2009). 
Managing EOL products according to strategies (S) 2, 3 and 4 bacis material flow

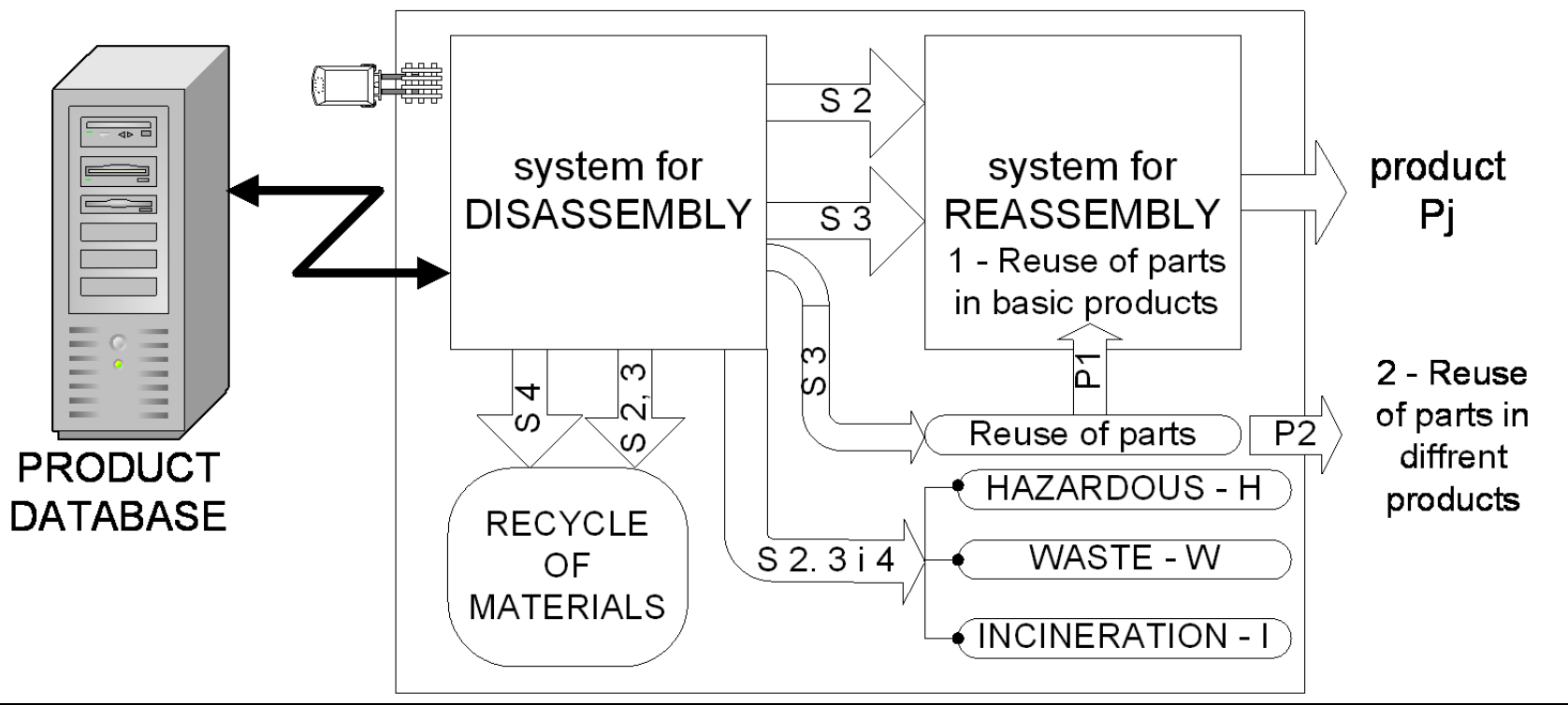

Fig. 5. System for processing the products at the end of the life cycle (Ostojic et al., 2008)

In the most general case, if for the given product (pi), all three potential strategies are chosen as possible, which comprise the need for disassembly (strategies 2, 3 and 4), then the production system for processing of such products contains in itself all the elements as in the previous figure. In case when only the strategy number 4 is chosen, then a subsystem for repair does not exist.

When choosing strategies 3 and 4, a subsystem for repair possibly exists. Depending on the type of product and the type of repair, the repair subsystem does not have to be specially separated. It is important to notice that in the procedure of the product disassembly, during the parts selection, a flow of materials must be planed for the parts that are headed for reassembly. In other words, it is often very possible to conduct, in a same place, within one subsystem where the disassembly is conducted, a second assembly of the product. In order to ensure the adequate supervision and control in all the phases of the product life cycle (depending on the type of product and level of supervision and control), an appropriate automated system is designed. Hardware system elements depend of the function to be executed in specific phases of the product life cycle, but the basic component is only a PC with Intranet/Internet connection and any kind of Internet browser. This kind of system enables only supervision in some of the phases where this supervision function should be available. This basic system can be expanded by adding a RFID reader and its connection to PC (RS 232, USB, or TCP/IP), but only in some of the phases of the product life cycle, where the control function is needed. The software system components include web-based application software, and the software application depends directly on selected products end-of-life strategy defined in the product design phase.

As presented in Fig. 4. and 5., the automated system for product monitoring enables interactive communication between the database, user and product in every phase of the product life cycle. The system designed in this way enables authorized 
users (Fig. 6.) to get an insight into the momentary status of a particular product, since the status of the product is changing from phase to phase during the life cycle.

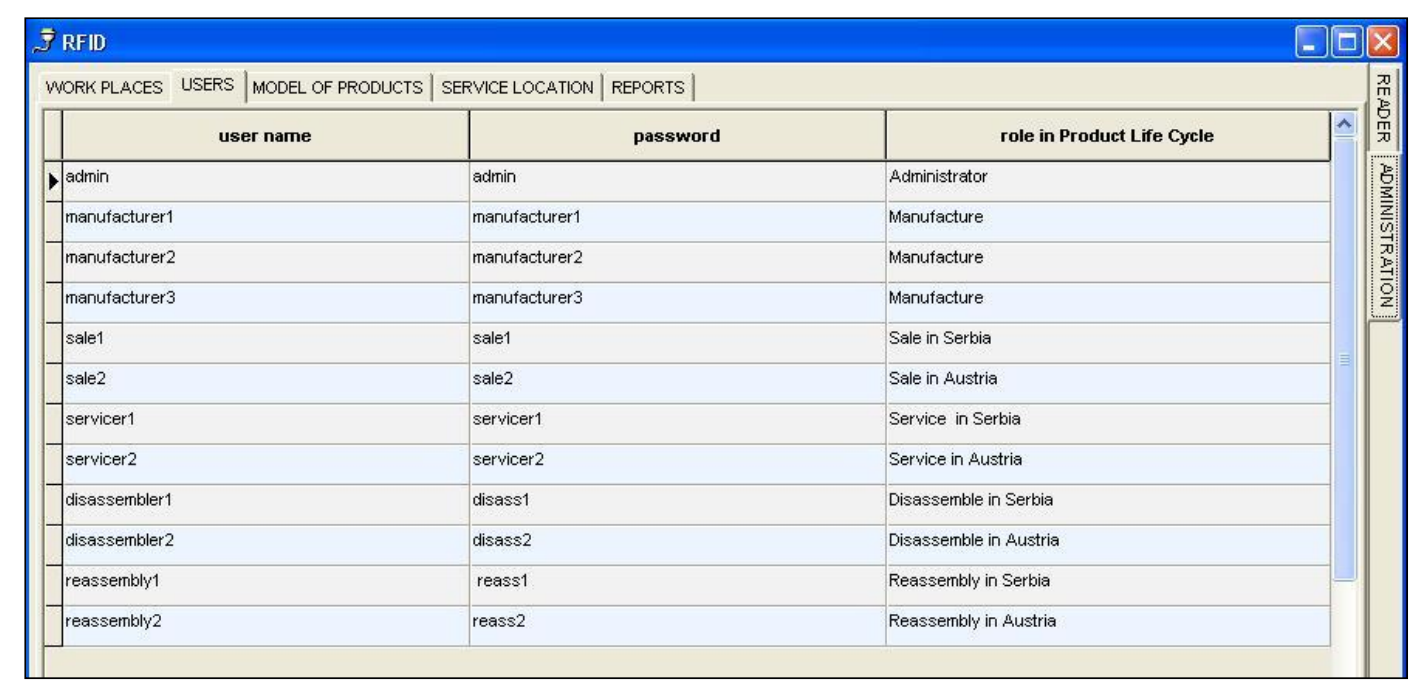

Fig. 6. Authorized users of web-based application software

In some phases, during the product life cycle, it is necessary to change information about the product. This activity is done by authorized users responsible for writing this information, whether only to the database or both to the database and RFID tag placed on the product, thus enabling updating information about the current status of the product. Information placed in the database about a product includes:

- Product ID (UID read from the RFID tag assigned to a particular product).

- Product type.

- Date of issue.

- Date of first start.

- Recommended strategy for product.

- Recommended level of disassembly depending on the chosen strategy for the product.

- What elements can be used for spare parts?

- Services (dates and descriptions).

- Number of working cycles.

- Does it contain hazardous parts and materials?

- Does it contain already used parts or recycled materials? If so, which parts are those and what is the number of the remaining working cycles?

- Which part is the base part for assembly? etc.

Since assembly and disassembly phases of product life cycle are one of the most important special attention has been given to the structure of these systems. An example of RFID technology application is shown in Fig. 7. The proposed concept can be used for assembly and disassembly of product in order to increase flexibility and efficiency rate of the system in hand. Products can be assembled and 
Stankovski, S. \& Ostojic, G: Challenges in Implementation of Automated Identifica...

disassembled on the same technological system according to the process plan and the product currently available at a particular working place.

An example of assembly is given in Fig. 7 and it follows the next routine: conveyer belt brings in the parts tagged with RFID. Upon arrival of the part at the first working place, the reader reads the RFID tag. The read out UID is compared to the UID from the data base, after which the data base issues a number of instructions for assembly presented graphically on-screen to the operator. The instructions are presented in a sequential manner, and are executed by taking the appropriate tool. Upon return of the tool to its previous position, next assembly instruction is initiated.

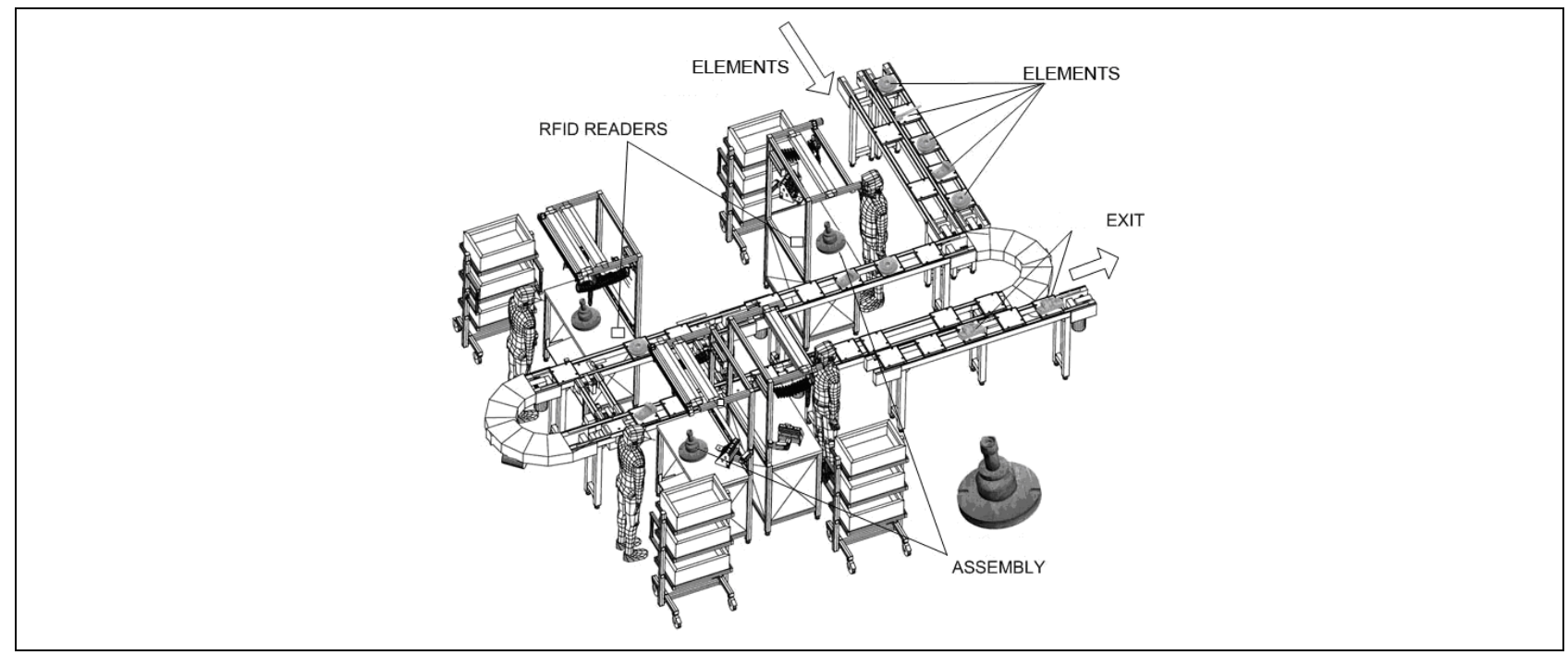

Fig. 7. Application of RFID in product assembly (Vukelic et al., 2010)

If a sequence requires no tool, then the next instruction must be initiated manually. Upon completion of the operation (all sequence of operation), the sequence of instruction for that particular working place is finished. The product is placed on the conveyor belt, travels along and, gets identified by RFID once again on another working place. If the product is to be machined at that particular working place, the signal light flashes and the operator takes the product off the conveyor belt. The process continues like in previous operation with a number of instructions coded for that working place and that product. In case all working places are currently busy, the product circles on the conveyor belt until a vacancy appears. The RFID tag is always placed on the base part.

\section{AIT in Agricultural Business}

The identification of cattle on the territory of the Republic of Serbia is obligatory. It is performed within 20 days after birth or before leaving the birth farm, by double ear labels on both ears fixed through the auricle. The ear labels have a unified code for the identification of each calf individually. This code is in a form of barcode with the structure represented in Fig. 8. The first two letters represent the country code, while the ten-digit number represents the unique number assigned to the particular animal. The first digit is the country code (7 - Serbia), the second digit 
is the cattle breed code $(1-$ cow $)$, the third digit is a control digit assigned by the Central base, and the remaining 7 digits are the animal identifier.

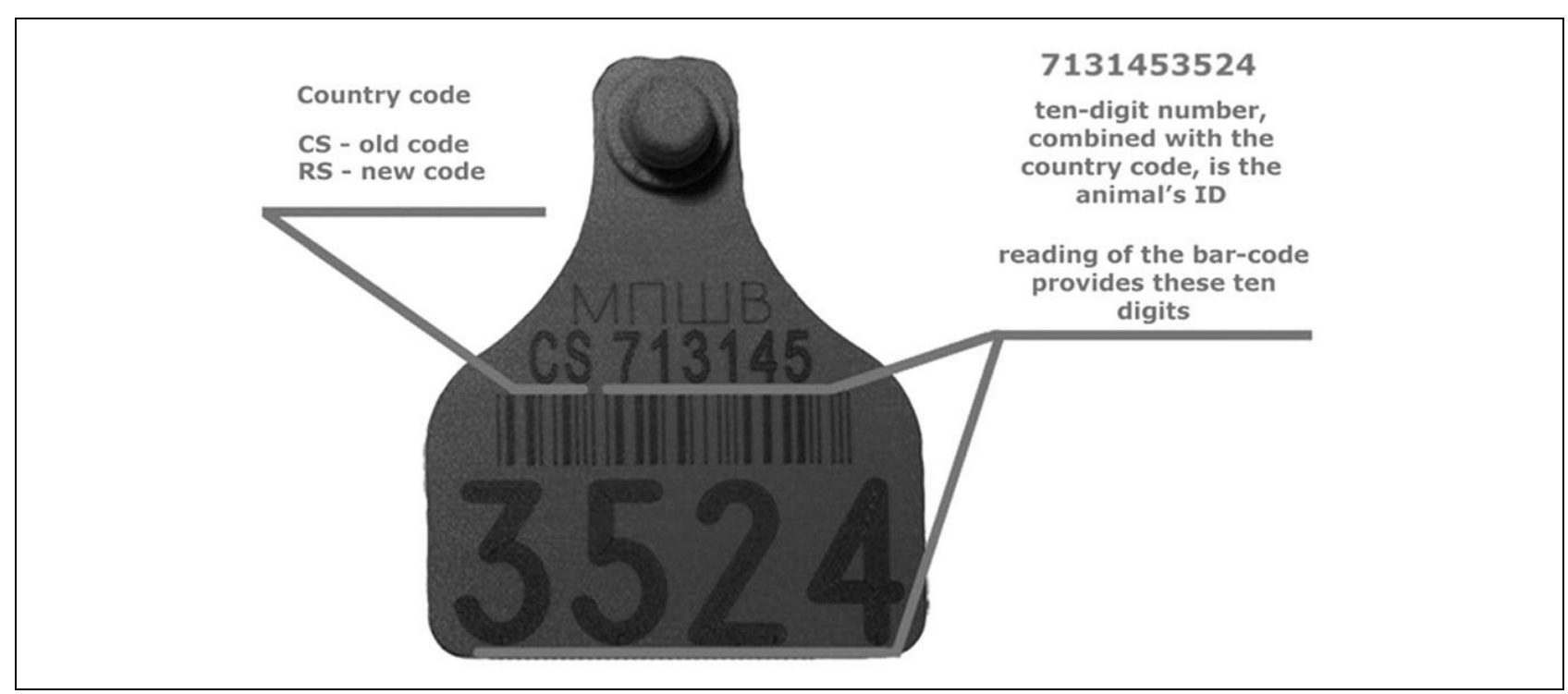

Fig. 8. Ear label with identification number

In the research that has been carried out on farms, barcode identification has proved inefficient for many reasons, e.g.:

- To identify the animal, as barcode reading is possible only on short distances, one must physically approach the animal, which disturbs it.

- The farm worker must spend his working time in data reading, which directly influences the farm's productivity and expenses.

- Errors occur during the manual data input to the PC.

- As the animals are in a dirty environment, mud and other dirt are often found on the ear labels, which complicate the identification of the animal, as more reading attempts are required.

- Recording changes about the individual animal data is not possible locally, as barcode possesses no memory where the data can be stored, instead it is necessary to modify the data in a unified database, which can be inaccessible for different reasons (no adequate infrastructure, etc.), and also requires additional involvement of the user.

- Barcode dedicated to an animal can be used only once, as no modification of data is possible.

- Barcode can easily be duplicated, which opens the possibilities for abuse.

Taking into account the fact that the identification of cattle (dairy cows) is obligatory, and that it is being performed in the above described manner, as well as the problems noticed on the farms, the idea came up to use RFID technology for identification and milking cycle tracking for each calf (dairy cow), due to the importance of regular milking cycles. This is one of the key influencing parameters for achieving a better and higher quality milk yield. Monitoring of the milking cycles can bring benefit to the following: 
- By monitoring the entering sequence of cows to the milking facility, milk quality can be influenced (it is possible to monitor whether healthy animals come first, or the animals with suspicion of disease, or if the ill animals or animals under therapy come to the milking facility, whether the younger or the elder animals come first, etc).

- With reports on the milking cycle, animal management can be optimized by arranging the sequence of bringing the animals to the milking facility and avoiding their crowding at the entrance. This can reduce stress and agonistic interactions between the cows while they wait to enter the milking facility, which leads to better overall welfare of the cows, reduces the risk of hurting between the animals, etc.

- If the animal is being fed with concentrated meals, then by the report of the time spent in the milking facility and its production, the amount of food for the animal can be optimized.

An RFID-based dairy cow monitoring system has been implemented on a dairy farm with three hundred and five of all categories Holstein-Frisian breed in the municipality Vrbas in the Republic of Serbia, in February 2009, and it has been used until May 2009 for the purpose of this experiment. After that period it has been used in regular operation. This system is used not only for the identification of each calf, but also for monitoring the entire milking cycle. Milking system was herringbone and each cow was admitted through an entrance gate. The cows were washed under the sprinkler systems and each cow entered an individual box. This system not only provided safe and correct cow positioning, but there was also good visibility of the animal's udder to the milker. Also, it is important to mention that the cows were provided with feed concentrate, and the milker wiped the udder with cloth and put on the milking cluster. All cows were milked twice daily and the samplings were taken for each cow outcome by milk meters (Metatron 12), according to ICAR (International Committee for Animal Recording) rules. On the farm milk samples are collected ones in four weeks, but for experiment milk samples were collected each day and carried in the laboratory of the Agricultural Faculty in Novi Sad. These samples were representing the 24 hour milking period. Analyzes of the chemical components of milk samples (milk fat $(\mathrm{MF})$, protein $(\mathrm{P})$, lactose $(\mathrm{L})$, dry matter (DM)) are done with routine methods. Also, the total bacteriological count (TBC) is obtained by method - flow cytometry using Bacto-Scan (Foss Analytical equipment).

Statistical analyses (average values, standard deviation and t-test) were carried out through software Statistica 9.1 (from StatSoft, Inc.).

The advanced RFID system is implemented in the milking facility. The RFID system comprises the following major hardware components:

1. Control box, containing a computer connected to a system of uninterruptible power supply,

2. Two UHF RFID readers operating at frequency of $915 \mathrm{MHz}$ ((Fig. 9 a) and Fig. 9 b)), and

3. Two hundred and ten RFID tags glued onto the dairy cow ear labels (Fig. 10). 
The UHF RFID readers are placed at the entrance and the exit of the milking facility above the door so that they do not hinder in any way the entry/exit of dairy cows, nor the workers carrying out tasks in the facility. The maximum length at which a reliable UHF RFID tag data reading can be performed is $10 \mathrm{~m}$.
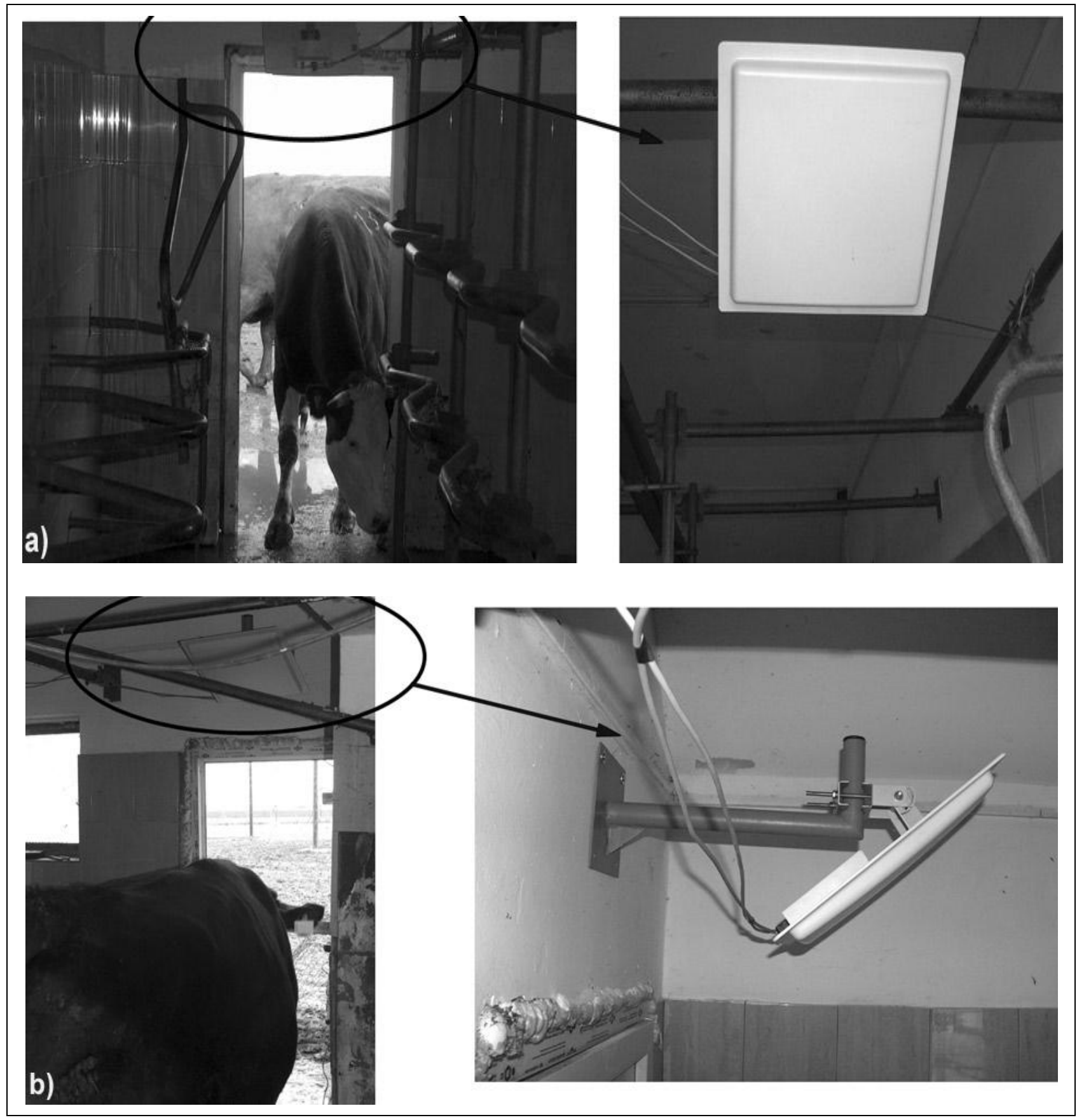

Fig. 9 a). RFID reader at the entrance to the milking facility; b) RFID reader at the exit from the milking facility

Since the UHF RFID technology allows longer distances for tag recognition (even up to 10 meters), the installation of RFID readers in the existing facilities is easier and does not affect to a larger extent the already established movement of cows 
Stankovski, S. \& Ostojic, G: Challenges in Implementation of Automated Identifica... within the room where the identification is being conducted (in this particular case: the milking facility).

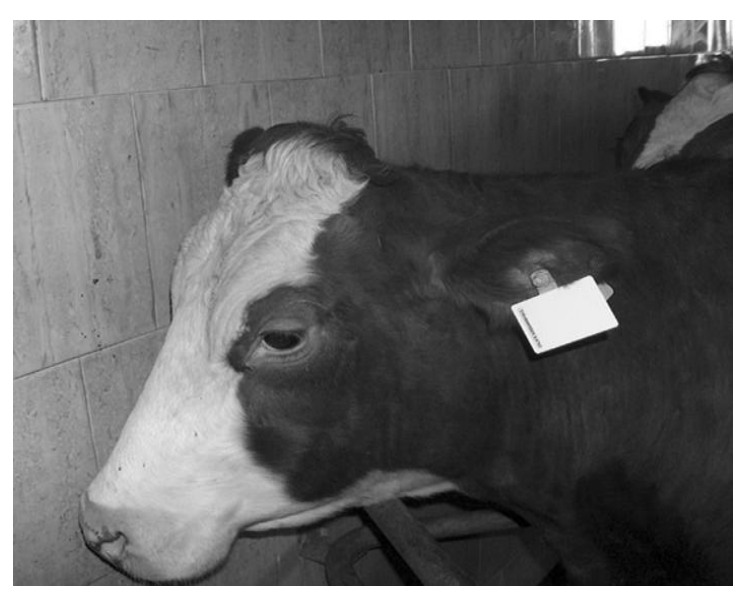

Fig. 10. The RFID tag on the ear label

The computer in the control box is primarily used for data acquisition from the RFID tags placed onto the ear labels and archive data on the hard disc of the computer. The following software components are installed on the computer:

1. An application which communicates with the RFID readers, and collects data from the RFID tags (UID - Unique Identifier, a single number for each card).

2. An application for the analysis of the data collected from the RFID tags for the purpose of identifying the milk cycle of each dairy cow.

These two applications enable monitoring, data acquisition, archive and analysis of a milk cycle of each dairy cow.

The experimental period at the farm lasted for 85 days. The owners of the small cattle farm could follow every step of the field trials, being able to understand the procedure. The results collected on the small cattle farm enabled the determination of behavioral patterns, i.e. it was possible to determine the order in which the cows were coming to the milking facility. Changes in this order were happening stochastically, which influenced the milk quality and yield of each dairy cow. Cows having a settled milking cycle within an interval of $12 \mathrm{~h} \pm 5 \%$ (group 1 ) had a $1.5 \%$ better daily milk yield and a 0.08 better quality in comparison to cows with a milking cycle variance higher than $20 \%$ (group 2). Average value \pm standard deviations of daily milk yield and milk quality are shown in Tab. 1.

\begin{tabular}{|l|l|l|l|l|l|l|}
\hline Group & MY $(\mathrm{kg})$ & MF \% & P \% & L \% & DM \% & TBC \\
\hline 1 & $27.1 \pm 5.35$ & $3.573 \pm 0.558$ & $3.201 \pm 0.323$ & $4.300 \pm 0.346$ & $12.302 \pm 0.743$ & $42589 \pm 8423$ \\
\hline 2 & $26.7 \pm 5.62$ & $3.571 \pm 0.700$ & $3.198 \pm 0.490$ & $4.297 \pm 0.269$ & $12.211 \pm 1.182$ & $42591 \pm 9280$ \\
\hline $\begin{array}{l}\text { P- } \\
\text { value }\end{array}$ & $0.0468^{*}$ & $0.4499^{\mathrm{nz}}$ & $0.5219^{\mathrm{nz}}$ & $0.5837^{\mathrm{nz}}$ & $0.0934^{\mathrm{nz}}$ & $0.4499^{\mathrm{nz}}$ \\
\hline
\end{tabular}

* Significant $\mathrm{p}<0.05$; NS- Not significant $\mathrm{p}>0.05$

Tab. 1. Average value \pm standard deviation of milk yield and milk quality and different between groups 
Low values of daily milk yield in group with a milking cycle variance higher than 20\% (group 2) are in according with other authors (Davis et al., 1999; Hale et al., 2003; Hassabo, 2009; Tagelsir, 1991). Circulatory and nervous system play an important role in milk synthesis, secretion and let down which is affected by neurohormonal effect and synchronization (Tagelsir, 1991). Becouse of that once a day milking or skipping milking is not acceptable with high producing dairy cows under intensified dairy system, while twice a day milking interval of 10-14 h and 12$14 \mathrm{~h}$ are acceptable, while 3 times a day milking will increase milk up to $12-15 \%$. Furthermore, four times a day milking will increase milk production from 8-12\% over, (Hassabo, 2009). Once-daily milking (ODM) of ruminants results in loss of milk production. In cows this loss is very variable between individuals but in recent short-term trials, on average, the loss was 13\% (Davis et al., 1999). Milking frequency can be increased in a manner that minimizes additional labour by employing unequal milking intervals (Hale et al. 2003). Total bacteriological count was in according with 39\% the best samples of Casoli et al. (2010). During the experimental period, no serious problems were detected. Animals responded well to tag application and no effect on the animals' welfare was observed. Moreover, the animal's health status was not affected by the devices because the UHF RFID tags were glued onto the dairy cow ear labels (Fig. 10). The only problem that was observed was related to the RFID reading accuracy. In the Tab. 2 the results of the RFID reading accuracy are presented. In order to remove faults due to the reading accuracy of the RFID reader or loss of ear tags, four additional ultrasonic sensors and four limit switches were placed. Each cow is located in a separate box and before the milking starts, the box must be closed, which is guaranteed by the signal from the matching limit switch. After that, the presence of cow in the box is determined and the cows are enumerated by using the ultrasonic sensors.

At the end of the milking cycle, the data about the enumerated cows from the RFID system and from the sensor system are compared. In case that these numbers do not match, the system generates a list of cows that were not identified by using the RFID system.

\begin{tabular}{|l|l|l|l|}
\hline $\begin{array}{l}\text { Reading accuracy during } \\
\text { experimental period }\end{array}$ & $\begin{array}{l}\text { Minimum per } \\
\text { day }\end{array}$ & $\begin{array}{l}\text { Maximum per } \\
\text { day }\end{array}$ & $\begin{array}{l}\text { Average per } \\
\text { period }\end{array}$ \\
\hline Period I (first week) & $94.8 \%$ & $98.6 \%$ & $97.3 \%$ \\
\hline $\begin{array}{l}\text { Period II (the rest of the } \\
\text { period) }\end{array}$ & $99.2 \%$ & $100 \%$ & $99.8 \%$ \\
\hline
\end{tabular}

Tab. 2. Results of the reading accuracy in the experimental period

During the first week of the experiment, the problem with the RFID reading accuracy was observed, and the necessary adjustments of the RFID readers were 
performed. After this period, the variations of the RFID reading accuracy were settled. For these reasons the results were represented in the form given in Tab. 2. The results acquired within the research led to the idea of designing a system that would generate a decision on the optimal path for each animal to the milking facility or the redirection to the waiting facility based on the established milking cycle for each animal and the determination of the actual situation at the entrance (identification of the animal currently at the entrance). It is important to emphasize that the animal identification process with the use of UHF RFID technology is such that at the time of identification the animal is not aware of the procedure, so the procedure does not cause stress, which would also have negative influence on the yield and quality of milk. This is not the case with the other identification methods, such as the manual or the automatic method which uses bar codes. Another advantage of the implemented system is that it can work autonomously, and, if required, it can be easily integrated into the new or existing complex farm management systems.

\section{Conclusion \& Future Challenges}

Automated identification technology is one of the most promising technologies in the future. Small and cheap electronic elements are enabled development of the identification devices with big processing power. These characteristics with communication are crucial to connection with wide range of devices, such as: computers, controllers, phones, etc. With these opportunities automated identification technology can be used in nearly every business in the world. In this moment, AIT is primarily used in applications such as tracking products and assets/supply chain, access control, health care systems, payments, etc.

Certainly, as one of the biggest challenges in the future will be monitoring and traceability of a food with the use of smart phones. This conclusion is coming from the fact that the food product traceability is a topic a lot of papers in main world journals. In order to set a traceability system, it is necessary to provide updated data that is significant to the user, such as the product origin, processing mode, storing conditions, expiration date etc. In each system there is a critical point where the systematic information loss occurs when the information about a product or process is not linked to a product and recorded systematically (Hu et al., 2013), thus it is important to set the system so that the potential critical points are recognized and the problems eliminated before the implementation of the traceability system.

The appearance of the avian and swine influenza, bovine spongiform encephalopathy ("the mad cow disease") as well as frequent occurrence of undesirable substances (pesticides, heavy metals, etc.) in food products increases the need for an efficient system for tracing the origin and the processing conditions of food during production, transport and warehousing. Product traceability is an efficient way for increasing food safety and quality and to reduce the expenses for withdrawal of problematic products from the market (Regattieri et al., 2007), as well 
as to improve production strategies in a company (Saltini and Akkerman, 2012) and production controll (Saltini et al., 2013). Product traceability is extremely important for perishable products industry (Lavelli, 2013). The European Union countries, this area is regulated with European standards for traceability and Best Available Technology (BAT), as laid down in EN ISO 2205:2007 standards and the European Directive 2008/1/EC (Standardization, 2007). On the other hand, it is shown that the modern way of life leads to separation of users (consumers) and producers of food products (farmers, agriculturalists) from each other (Frewer et al., 2005; Harper and Makatouni, 2002; María, 2006; Phuong, 2013; Verbeke, 2005). This separation influences the increase in consumers distrust in the food product quality, different interpretations of conditions in which the animals should be held in order to gain satisfactory quality of food products from a certain land property (Bosona and Gebresenbet, 2013; Vanhonacker et al., 2008).

A study (Zhang et al., 2012) shows that the consumers are willing to pay a significant positive price premium for food traceability, as such a system greatly influences the consumers trust in a certain product (Chen and Huang, 2013). (Cunha et al., 2010) shows a system for vineyard identification and vine origin based on a $Q R$ code printed on the container where the vine is transported. By reading the $\mathrm{QR}$ code by the mobile phone and using the internet, a user can get information about the origin, weather and other conditions in the field during the growth of grapes. This project also used other technologies, like the RFID tags, determining location by GPS, measurement of temperature, humidity and air pollution. A similar concept of traceability is shown in (Ruiz-Garcia et al., 2010), where data from the field are collected through web-based systems for data processing. There are also studies where product traceability is used in analysis of product quality at the end of product lifecycle and the products are classified based on these results (Papetti et al., 2012; Zhang et al., 2010). (Qian et al., 2012) describe a study with a primary goal to develop a Wheat Flour Milling Traceability System (WFMTS), incorporating 2D barcode and radio frequency identification (RFID) technology, and to validate the system in a wheat flour mill in Chinese. Tracing each individual product is based on 64 applications of QR codes, and tracing a container with several products is based on application of RFID tags. The system described by this study is successfully implemented in a real world application.

Application of 2D codes is also present at farms, and thus (Fröschle et al., 2009) presents results that indicate applicability of Data Matrix codes for product traceability for each individual animal at poultry farms. The codes are printed on the beak and feet of the animal, and the reading of codes is performed by optical devices. It was shown that the codes printed on the beak have better read rates than those printed on the feet. Another similar research (McInerney et al., 2011a, 2011b) analyzed the influence of renewing the surface of the chicken beak during the traceability period to the readability of linear and 2D barcodes that were printed on the beak. It was shown that regardless of the renewing of the beak cells, the codes are mostly readable. 
In the analysis of the data (www.firstdata.com), it is discovered that the biggest predictor of behaviour and attitudes is whether or not the consumer uses a smart phone. (All smart phones can be used as the part of AIT.) That differentiation is also driven by age, with Millennials (ages 18-34) leading the way, but Millennials are also more likely to own and use a smart phone. The analysis shows that nearly $100 \%$ mobile phone penetration among survey respondents, that smart phone penetration varies around the globe, with China (92\%), Singapore (89\%) and the Middle East (80\%) showing highest smart phone penetration. But even in countries later on the smart phone adoption curve, approximately one half already use a smart phone. In the United States, smart phone penetration up to 68\%, with large growth in the 55+ age group in the past six months alone. This is very important, because the $55+$ age group usually pays more attention to the quality of food. As a global average, $80 \%$ of Millennials use a smart phone, and it's just a matter of time before the majority of global consumers will be online anytime and anywhere. (This is truly challenges, not only for AIT!) This opportunity is crucial to success of all projects of monitoring and traceability of the food.

In this chapter is presented several application based on RFID technology (the core technology for identification in most applications) developed at Department of Industrial Engineering and Management, Faculty of Technical Sciences, University of Novi Sad. These applications are results of research in the fields: product lifecycle management, access control and agricultural business. Also, one of the future researches challenges of AIT is discussed.

\section{References}

Artmann, R. (1999). Electronic identification systems: state of the art and their further development. Computers and Electronics in Agriculture, Vol. 24, 5-26, ISSN 0168-1699

Balch, T.; Feldman, A. \& Wilson, W.P. (2004). Assessment of an RFID System for Animal Tracking. Georgia Institute of Technology, CC Technical Report; GIT-CC04-10. [Online]. Available at: http://smartech.gatech.edu/handle/1853/6495 [Accessed Jan. 30, 2011]

Bloss, R. (2006). Robots help label before molding. Industrial Robot. An International Journal, Vol. 33, No. 6, 425 - 427, ISSN 0143-991X

Bosona, T. \& Gebresenbet, G. (2013). Food traceability as an integral part of logistics management in food and agricultural supply chain. Food Control, Vol. 33, 32-48, ISSN 0956-7135

Cassoli, L.D.; Francischetti, G.; Machado, P.F. \& Mourão, G.B. (2010). The relationship of flow cytometry results with classical measures of bacterial counts in raw refrigerated milk. International Journal of Dairy Technology, Vol. 63, 297-300, ISSN 1364-727X 
Chen, M.-F. \& Huang, C.-H. (2013). The impacts of the food traceability system and consumer involvement on consumers' purchase intentions toward fast foods. Food Control, Vol. 33, 313-319, ISSN 0956-7135

Cunha, C.R.; Peres, E.; Morais, R.; Oliveira, A.; Matos, S.G.; Fernandes, M.; Ferreira, P.J.S.G. \& Reis, M.J.C.S. (2010). The use of mobile devices with multi-tag technologies for an overall contextualized vineyard management. Computers and Electronics in Agriculture, Vol. 73, 154-164, ISSN 0168-1699

Davis, S. R.; Farr, V. C. \& Stelwagen, K. (1999). Regulation of yield loss and milk composition during once-daily milking. Livestock Production Science, Vol. 59, 77 94, ISSN 0301-6226

Eradus, W. \& Janssen, B. (1999). Animal identification and monitoring. Computers and Electronics in Agriculture, Vol. 24, 91-98, ISSN 0168-1699

Frewer, L.J.; Kole, A.; Kroon, S.M. \& Lauwere, C.D. (2005). Consumer Attitudes Towards the Development of Animal-Friendly Husbandry Systems. Journal of Agricultural and Environmental Ethics, Vol. 18, 345-367, ISSN 1187-7863

Fröschle, H.-K.; Gonzales-Barron, U.; McDonnell, K. \& Ward, S. (2009). Investigation of the potential use of e-tracking and tracing of poultry using linear and 2D barcodes. Computers and Electronics in Agriculture, Vol. 66, 126-132, ISSN 0168-1699

Glover, B. \& Bhatt, H. (2006). RFID Essentials, O'Reilly, ISBN 978-0-596-00944-1

Gubbi, J.; Buyya, R.; Marusic, S. \& Palaniswami, M. (2013). Internet of Things (IoT): A vision, architectural elements, and future directions, Future Generation Computer Systems, Vol. 29, No. 7, 1645-1660, ISSN 0167-739X

Hale, S.A; Capuco, A.V. \& Erdman, R.A. (2003). Milk Yield and Mammary Growth Effects Due to Increased Milking Frequency During Early Lactation. Journal of Dairy Science, Vol. 86, 2061-2071, ISSN 0022-0302

Harper, G.C. \& Makatouni, A., (2002). Consumer perception of organic food production and farm animal welfare. British Food Journal, Vol. 104, 287-299, 0007 070X

Hassabo, A.A. (2009). Effect of Frequency of Milking Local Sudanese Cows (Kenana-Butana) on Total Yield. Pakistan Journal of Nutrition, Vol. 8, No. 9, 13541355, ISSN: 1680-5194

Hu, J.; Zhang, X.; Moga, L.M. \& Neculita, M. (2013). Modeling and implementation of the vegetable supply chain traceability system. Food Control, Vol. 30, 341-353, ISSN 0956-7135

Hyland, I. (2001). Robots used on plastic injection moulding machines. Industrial Robot. An International Journal, Vol. 28, No. 2, 104 - 112, ISSN 0143-991X.

Inkenzeller, K. (2003). RFID Handbook: Fundamentals and Applications in Contactless Smart Cards and Identification, John Wiley and Sons., ISBN 978-0-47084402-1

Karakostas, B. (2013). A DNS Architecture for the Internet of Things: A Case Study in Transport Logistics, Procedia Computer Science, Vol. 19, 594-601, ISSN 18770509 
Stankovski, S. \& Ostojic, G: Challenges in Implementation of Automated Identifica...

Karkkainen, M.; Ala-Risku, T. (2003). Automatic identification - applications and technologies, Proceedings of the Logistics Research Network (LRN) 8 th annual conference, London, UK, September 2003

Klindtworth, M.; Wendl, G.; Klindtworth, K. \& Pirkelmann, H. (1999). Electronic identification of cattle with injectable transponders. Computers and Electronics in Agriculture, Vol. 24, 65-79, ISSN 0168-1699

Lahiri, S. (2007). RFID Sourcebook. IBM Press Pearson plc, ISBN 978-0-13-1851375 , New York, USA

Lavelli, V. (2013). High-warranty traceability system in the poultry meat supply chain: A medium-sized enterprise case study. Food Control, Vol. 33, 148-156, ISSN 0956-7135

Lazarevic, M. (2009). Developement of a model for Product Life Cycle Management with the usage of RFID Technology, Doctoral Thesis, Republic of Serbia

Leng Ng, M.; Seong Leong, S.; Hall, D.M. \& Cole, P.H. (2005). A small passive UHF RFID tag for livestock identification. Proceedings of IEEE International Symposium on Microwave, Antenna, Propagation and EMC Technologies for Wireless Communications, Vol. 1, pp. 67-70, ISBN 0-7803-9128-4, Aug. 2005.

Maksimovic, R.; Stankovski, S., Ostojic, G., Petrovic, S. \& Ratkovic, Z. (2010). Complexity and Flexibility of Production Structures. Journal of Scientific and Industrial Research (JSIR), Vol. 69, 101-105, ISSN 0022-4456

María, G.A., (2006). Public perception of farm animal welfare in Spain. Livestock Science, Vol. 103, 250-256, ISSN 1871-1413

Mc Inerney, B.; Corkery, G.; Ayalew, G.; Ward, S. \& Mc Donnell, K. (2011a). Preliminary in vivo study on the potential application of a novel method of etracking to facilitate traceability in the poultry food chain. Computers and Electronics in Agriculture, Vol. 77, 1-6, ISSN 0168-1699

Mc Inerney, B.; Corkery, G.; Ayalew, G.; Ward, S. \& Mc Donnell, K. (2011b). A preliminary in vivo study on the potential application of a novel method of e-tracking in the poultry food chain and its potential impact on animal welfare. Computers and Electronics in Agriculture, Vol. 79, 51-62, ISSN 0168-1699

McKean, J. (2001). The importance of traceability for public health and consumer protection. Revue Scientifique et Technique. Office International des Epizooties, Vol. 20, 363-371, ISSN 0253-1933

Mehl, C.; Beiter, A. \& Ishii, K. (1994). Design for Injection Molding: Using Dimensional Analysis to Assess Fillability, Proceedings of the 1994 ASME Design Automation Conference, Minneapolis, MN

Ntafis, V.; Patrikakis, C.; Xylouri, E. \& Frangiadaki, I. (2008). RFID Application in animal monitoring. In: The Internet of Things: from RFID to Pervasive Networked Systems, Yan, L.; Zhang, Y.; Yang, L.T.; Ning, H., (Ed.) p. 165-184. Auerbach Publications, ISBN 978-1-42-005281-7

O'Connor, M.C. (2009). Danish Dairies Adopt RFID to Improve Yield. [Online]. Available at: http://rfidjournal. com/article/view/5083. [Accessed Jan. 30, 2011] 
Ostojic, G.; Lazarevic, M.; Stankovski, S., Cosic, I. \& Radosavljevic, Z. (2008). Radio Frequency Identification Technology Application in Disassembly Systems. Strojniški vestnik - Journal of Mechanical Engineering, Vol. 54, No. 11, 759-767, ISSN 0039-2480

Ostojic, G.; Stankovski, S. \& Lazarevic, M. (2007) Implementation of RFID Technology in Parking Lot Access Control System, Proceedings of the 1. IEEE RFID Eurasia, pp. 49-53, ISBN 978-975-01566-0-1, Istanbul Technical University, Septembar 2007, Istanbul

Ostojic, G.; Stankovski, S., Tarjan, L., Senk, I. \& Jovanovic, V. (2010). Development and Implementation of Didactic Sets in Mechatronics and Industrial Engineering Courses. International Journal of Engeneering Education, Vol. 26, No. 1, 2-8, ISSN 0949-149X

Papetti, P.; Costa, C.; Antonucci, F.; Figorilli, S.; Solaini, S. \& Menesatti, P. (2012). A RFID web-based infotracing system for the artisanal Italian cheese quality traceability. Food Control, Vol. 27, 234-241, ISSN 0956-7135

Phuong, N.T. (2013). Consumers' perceptions of organic food in Australia and other countries: A review. Journal of Agricultural Economics and Development, Vol. 2, 44-54, ISSN 2006-9774

Qian, J.-P.; Yang, X.-T.; Wu, X.-M.; Zhao, L.; Fan, B.-L. \& Xing, B. (2012). A traceability system incorporating 2D barcode and RFID technology for wheat flour mills. Computers and Electronics in Agriculture, Vol. 89, 76-85, ISSN 0168-1699

Regattieri, A.; Gamberi, M. \& Manzini, R. (2007). Traceability of food products: General framework and experimental evidence. Journal of Food Engineering, Vol. 81, 347-356, ISSN 0260-8774

Rose, C.M. \& Ishii, K. (1999). Product End-of-Life Strategy Categorization Design Tool. Journal of Electronics Manufacturing, Vol. 9, 41-51, ISSN 0960-3131

Saltini, R. \& Akkerman, R. (2012). Testing improvements in the chocolate traceability system: Impact on product recalls and production efficiency. Food Control, Vol. 23, 221-226, ISSN 0956-7135

Saltini, R.; Akkerman, R. \& Frosch, S. (2013). Optimizing chocolate production through traceability: 400 A review of the influence of farming practices on cocoa bean quality. Food Control, Vol. 29, 167-187, ISSN 0956-7135

Samada, A.; Murdeshwarb, P. \& Hameed, Z. (2010). High-credibility RFID-based animal data recording system suitable for small-holding rural dairy farmers. Computers and Electronics in Agriculture, Vol. 73, 213-218, ISSN 0168-1699

Shepard, S. (2005). RFID - Radio Frequency Identification, McGraw-Hill, ISBN 978-0071442992

Standardization, I.O.F., (2007). New ISO standard to facilitate traceability in food supply chains. ISO 22005:2007

Stankovski, S.; Lazarevic, M., Ostojic, G., Cosic, I. \& Puric R. (2009a). RFID Technology in Product/Part Tracking During the Whole Life Cycle. Assembly Automation, Vol. 29, No. 4, 364-370, ISSN 0144-5154 
Stankovski, S.; Ostojic, G. \& Lazarevic, M. (2010). Chapter 14: RFID technology in product lifecycle management, Engineering the Future, Bombay, Scyio, pp. 281-296, ISBN 978-953-307-210-4

Stankovski, S.; Ostojic, G., Tarjan, L., Skrinjar, D. \& Lazarevic, M. (2011). IML Robot Grasping Process Improvement. Iranian Journal of Science \& TechnologyTransactions B, Vol. 35, No. M1, 197-207, ISSN 1028-6284

Stankovski, S.; Ostojic, G.; Jovanovic, V. \& Stevanov, B. (2006). Using RFID Technology in Collaborative Design of the Assembly Systems. Facta Universitatis, Series: Mechanical Engineering, Vol. 4, No. 1, 75 - 82, ISSN 0354-2025

Stankovski, S.; Ostojic, G.; Senk, I.; Rakic-Skokovic, M.; Trivunovic, S. \& Kucevic, D. (2012). Dairy cow monitoring by RFID, Scientia Agricola, Vol. 69, No 1, 75-80, ISSN 0103-9016

Stankovski, S.; Tarjan, L., Skrinjar, D., Ostojic, G. \& Senk, I. (2009b). Using a Didactic Manipulator in Mechatronics and Industrial Engineering Courses. IEEE Transactions on Education, Vol. 53, No. 4, 572-579, ISSN 0018-9359. DOI: 10.1109/TE.2009.2036002

Tagelsir, E.A. (1991). Some genetical and environmental factors effecting birth weight of Butana subtype and Frisian and Kenana crosses at Atbra and Nsheshesh Research Centeres. Journal of Animal Production, Vol. 4, ISSN 1411-2027

Trevarthen, A. \& Michael, K. (2008). The RFID-Enabled Dairy Farm: Towards Total Farm Management. Proceedings of the Seventh International Conference on Mobile Business. p. 1-10, June 2008, Barcelona, Spain, IEEE Computer Society

Turcua, C.E. \& Turcua, C.O. (2013). Internet of Things as Key Enabler for Sustainable Healthcare Delivery, Procedia - Social and Behavioral Sciences, Vol. 73, 251 - 256, ISSN 1877-0428

United States Department of Agriculture. (2009). A Focus on Animal Electronic Identification [Online]. Available at: http://healthymeals.nal.usda.gov/fsrio/ document_fsheet.php?product_id=61 [Accessed Aug. 28, 2009]

Vanhonacker, F.; Verbeke, W.; Van Poucke, E. \& Tuyttens, F. (2008). Do citizens and farmers interpret the concept of farm animal welfare differently? Livestock Science, Vol. 116, 126-136, ISSN 1871-1413

Verbeke, W. (2005). Agriculture and the food industry in the information age. European Review of Agricultural Economics, Vol. 32, 347-368, ISSN 0165-1587.

Voulodimos, A.; Patrikakis, C.; Sideridis, A.; Ntafis, V. \& Xylouri, E. (2010). A complete farm management system based on animal identification using RFID technology. Computers and Electronics in Agriculture, Vol. 70, 380-388, ISSN 0168-1699

Vukelic, Dj.; Ostojic, G.; Stankovski, S.; Lazarevic, M.; Tadic, B.; Hodolic, J. \& Simeunovic, N. (2011). Machining Fixture Assembly/Disassembly in RFID Environment. Assembly Automation, Vol. 31, No. 1, 62-68, ISSN 0144-5154

Zhang, C.; Bai, J. \& Wahl, T.I. (2012). Consumers' willingness to pay for traceable pork, milk, and cooking oil in Nanjing, China. Food Control, Vol. 27, 21-28, ISSN 0956-7135 